\title{
КОМУНІКАТИВНІ ОЗНАКИ РЕЦЕНЗІЙНОГО ДИСКУРСУ
}

\author{
ІРИНА ЛЕВЧУК \\ Волинський національний університет імені Лесі Українки, Луцьк - Україна
}

\section{KOMUNIKATYWNE CECHY DYSKURSU RECENZJI}

\author{
IRYNA LEWCZUK
}

Wołyński Państwowy Uniwersytet imienia Łesi Ukrainki, Łuck — Ukraina

STRESZCZENIE. W artykule przedstawiono szczegóły dyskursu recenzji jako składnika komunikacji naukowej, określono jego cechy podstawowe. Główną uwagę skupiono wokół opisu właściwości funkcjonalno-komunikatywnych dyskursu recenzji.

\section{COMMUNICATIVE PECULIARITIES OF REVIEW DISCOURSE}

\section{IRYNA LEVCHUK}

Volyn' Lesya Ukrainka National University, Luts'k — Ukraine

ABSRACT. The article focuses on the peculiarities of the review discourse as a constituent of scientific communication. Its main features have been determined in the article. The main attention has been paid to the description of functional-communicative peculiarities of the review discourse.

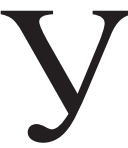

сучасній лінгвістиці увагу дослідників привертає специфіка наукової комунікації. 3-поміж здобутків у цій галузі відзначимо зокрема монографію А. Коваль ${ }^{1}$ щодо особливостей структурної організації українського наукового тексту. Семантико-синтаксичний аспект наукового стилю досліджувала й С. Срмоленко ${ }^{2}$. Функціонально-стилістичні особливості науково-технічної літератури розглянуто Н. Непийводою ${ }^{3}$. Функціонально-стильові домінанти наукових текстів описано також у підручниках зі стилістики А. Коваль, О. Пономарева, Л. Мацько, О. Сидоренко, О. Мацько та посібниках Н. Бабич, П. Дудика. Особливості структурної організації різножанрових текстів наукового стилю, механізми функціонування сучасної наукової мови розглянуто Г. Онуфрієнко $^{4}$. У російській мовознавчій науці специфіці наукового стилю присвячені розвідки Пермської школи функціональної стилістики, зокрема питання діалогічності наукового тексту та системності наукового стилю загалом грунтовно проаналізовано в працях М. Кожиної5, основні ознаки жанрів наукової літератури з'ясовано в дослідженнях О. Троянської ${ }^{6}$ Специфіку наукової комунікації

${ }^{1}$ А. П. Коваль, Науковий стиль сучасної украӥнської мови, [в:] Структура наукового тексту, Київ 1970.

${ }^{2}$ С. Я. Срмоленко, Синтаксис і стилістична семантика, Київ 1982.

3 Н. Ф. Непийвода, Мова украӥнської науково-технічної літератури (функціональностилістичний аспект), Київ 1997.

${ }^{4}$ Г. С. Онуфріє нко, Науковий стиль української мови, Київ 2006.

${ }^{5}$ М. Н. Кожина, О диалогичности письменной научной речи, Пермь 1986.

${ }^{6}$ Е. С. Троян ская, Научное произведение в оченке автора рецензии, [в:] Научная литература: Язык, стиль, жанры, Москва 1985, с. 67-81. 
у російській мові розглянуто в статтях О. Баженовоїㄱ, Н. Данилевської ченко ${ }^{9}$, Т. Мальчевської ${ }^{10}$, Л. Славгородської ${ }^{11}$, Н. Соловйової ${ }^{12}$ та ін.

Об’єктом більшості досліджень слугують тексти „ядрових” жанрів наукового стилю (статті та монографії), водночас „периферійні” жанри (анотація, реферат, повідомлення, тези, патент та ін. ${ }^{13}$ залишаються меншою мірою репрезентованими в мовознавчих студіях. Проте зі зростанням інтересу до вивчення специфіки організації та ведення наукових дискусій, актуальності набуває дослідження рецензійного дискурсу як безпосереднього ііі втілення.

Термін „рецензія”, як відомо, походить від лат. recensio, що значить „огляд”, „розгляд”, „оцінка”. Літературознавчий словник-довідник пропонує таку дефініцію: „Рецензія - один із провідних жанрів літературної критики, що розглядає й оцінює твори художньої літератури, мистецтва, визначає їх вартість та характеризує допущені, на думку критика, хиби, недоліки" ${ }^{14}$. Проте це лише один із аспектів розуміння жанру рецензії.

У російському літературному енциклопедичному словнику це поняття репрезентовано значно ширше: по-перше, як „відгук, розбір й оцінка нового художнього (літературного, театрального, музичного, кінематографічного тощо), наукового чи науково-популярного твору;” по-друге, як „жанр критики літературної та газетно-журнальної публіцистики"

Серед журналістів побутує тлумачення рецензії як різновиду статті, що „відображає явища та факти не суспільного життя загалом, а тільки з літературної, театральної, художньої, музичної його сфер"'16.

О. Сальникова, пропонуючи визначення рецензії, звертає увагу передусім на їі функціональну специфіку: „Рецензія — це більш або менш цілісний аналіз твору з оцінною спрямованістю, до того ж, рецензент прагне не тільки обгрунтувати свою позицію, але й привернути увагу читача до рецензованого твору" ${ }^{17}$.

Аналізуючи особливості змістового та функціонального аспектів рецензії, Н. Колесникова формулює відповідну дефініцію, враховуючи три обов'язкові складники такого тексту: 1) коментування основних положень (тлумачення авторської позиції); власне доповнення думок, висловлених автором; виражен-

${ }^{7}$ Е. А. Бажен ова, Научный текст и среда, [в:] „Вестник Пермского университета”, Пермь 2010, вып. 2, с. 60-64.

${ }^{8}$ Н. В. Данилевская, Научный текст как динамика оиеночных действий, [в:] „Вестник Пермского университета", вып. 2, Пермь 2009, с. 20-28.

${ }^{9}$ Н. В. Кириченко, Функиионирование средств экспрессивного синтаксиса в текстовой структуре научно-популярного произведения, [в:] Типология текста в функииональностилистическом аспекте, Пермь 1990, с. 47-58.

${ }^{10}$ T. Н. Мальчевская, Специфика научных текстов и принцииы их классификации (на материале английских биологических текстов), [в:] Особенности стиля научного изложения, Москва 1976, с. 104-116.

${ }^{11}$ Л. В. Славгородская, Научный диалог (лингвистические проблемы), Ленинград 1986.

${ }^{12}$ Н. В. Солов ьева, Стратегии презентации коммуникантов в текстах научных дискуссий, [в:] "Вестник Пермского университета", Пермь 2019, вып. 1, с. 29-37.

${ }^{13}$ Е.С.Троянская, Научное произведение в оценке автора рецензии, [в:] Научная литература: Язык, стиль, жанры, Москва 1985, с. 67.

${ }^{14}$ Літературознавчий словник-довідник, за ред. Р. Т. Гром'яка, Ю. І. Коваліва та ін., Київ 1997, c. 242.

${ }^{15}$ Литературный энииклопедический словарь, под общ. ред. В. М. Кожевникова, П. А. Николаева, Москва 1987, с. 322.

${ }^{16}$ В. Карпенко, Основи професіональної комунікації, Київ 2002, с. 213-214.

17 3. С. Смелкова, Л. В. Ассуирова и др. Риторические основы журналистики. Работа над жанрами газеты, Москва 2002, с. 205. 
ня свого ставлення до певної проблеми тощо; 2) узагальнена аргументована оцінка і 3) висновки про значення твору ${ }^{18}$.

Існує думка, що рецензія виникла з бібліографічного опису книги, який iз часом почав давати також іiї оцінку. Із появою в журналах рубрики "Критика" (в українській періодиці XIX ст., скажімо, поширеною була рубрика „Справозданє") рецензія стала здебільшого журнальним жанром.

Оскільки рецензія, як і реферат чи анотація, з'являється лише у зв'язку 3 певним уже існуючим „первинним” текстом, то, очевидно, іiї ознакою $є$ „вторинність”. Об'єктом наукової рецензії слугують не безпосередні факти дійсності, на яких грунтуються праці вчених, а факти, явища, вже вивчені, осмислені та подані у формі відповідних публікацій. Свого часу відібраний і узагальнений матеріал ніби знову переосмислюється рецензентом, який на основі аргументованого аналізу праці вченого виявляє важливі й актуальні аспекти змісту, висловлює свої думки у зв'язку з рецензованим твором, оцінює його. О. Кудасова зауважує, що „наявність в рецензії інформації інтелективного плану, а також інформації про структуру рецензованого твору підтверджує думку про вторинний характер тексту рецензії'19.

Проте рецензія може мати почасти елементи оригінального наукового твору, що створюється на основі рецензованої книги, але все ж ніби відокремлено від неї та містить наукові судження самого рецензента щодо конкретної проблеми (чи проблем). Традиційно розрізняють два типи рецензій: такі, що з’являються до виходу праці у світ і після іiі публікації, тобто мають проспективний або ретроспективний характер.

Оцінка певного наукового дослідження - основне комунікативне завдання рецензії. Саме оцінка формує ціннісні орієнтири читача, дає змогу йому зорієнтуватися в безперервному потоці інформації, вибрати потрібну книгу. Щоправда, нерідко є й такі рецензії, що лише розглядають зміст книги, сконденсовано переказуючи іiі. Але й такий підхід може бути виправданий, оскільки рецензент у такий спосіб вирізняє найсуттєвіше в аналізованому творі, детально зупиняючись на певних положеннях і повністю опускаючи інші, а отже, й виявляє своє ставлення до повідомлюваного. Отож, рецензія, крім повідомлення читачеві про зміст книги та її оцінки, є ще й своєрідним засобом реклами того чи того твору. До вторинних функцій рецензії належить також встановлення та відбір критеріїв оцінки наукової праці та системи вимог до неї. Очевидно, варто виділяти й прагматичну функцію організації наукового спілкування, пов’язану передусім із виробленням вербальних форм наукового етикету. Усі композиційні та мовні структури рецензії спрямовані на максимально ефективну реалізацію цих функцій.

Рецензії, як показує практика, не пишуться за єдиним зразком. Залежно від галузі знань структурно-семантична організація рецензії може змінюватися, зокрема упорядкування структурних елементів літературознавчої та мовознавчої рецензії зумовлюють такі чинники, як жанр аналізованої книги (чи то монографія, чи збірник праць, чи художній твір (прозовий або поетичний)); реальна проблема, що порушена автором рецензованого твору.

Не викликає сумнівів і те, що вибір композиційних елементів тексту та їх конкретне мовне наповнення перебуває також у прямій залежності від автор-

${ }^{18}$ Н. И. Колесникова, От конспекта к диссертации, Москва 2002, с. 230.

19 О. К. Кудасова, Лингвистические особенности рецензии как разновидности научного текста (на материале английского языка), автореф. дис. канд. филол. наук, Москва 1983, с. 3. 
ського „я": в одних рецензіях основною метою може бути оцінка позитивого й критика недоліків, а в інших, - у центрі уваги постають судження автора про роль і місце в науці тієї галузі знання, котрій присвячена книга. Зрештою, індивідуально-авторський чинник певною мірою визначає структуру навіть тих рецензій, автори яких обмежуються тільки викладом змісту книги. Проте вже сам характер інтерпретації змісту може бути імпліцитною оцінкою праці.

Безумовно, структура тексту значною мірою зумовлена і його стилем та жанром. Сучасні літературознавці виокремлюють такі різновиди жанру рецензії, як анотація, коротка рецензія (відгук), реферативна рецензія, звичайна газетна (журнальна) рецензія, проблемна рецензія, рецензія-есе, -діалог, -фейлетон, -памфлет, -жарт, -лист, авторецензія, рецензентська репліка ${ }^{20}$.

Розглянемо детальніше журнальну рецензію, що визначається В. Ляпуновою, О. Мєшковим ${ }^{21}$ та іншими дослідниками як жанр наукової публіцистики. Проникнення елементів публіцистики в текст рецензії зумовлено тим, що автор застосовує не лише логічне доведення певних наукових положень, але й переконання. Рецензент прагне не лише інформувати читача, а й зацікавити, спонукати в такий спосіб до прочитання книги.

Журнальна рецензія характеризується такими ознаками наукового стилю, як логічна послідовність висловлення, точність, ясність, чіткість інформації, аргументованість, узагальнення. 3 цих найзагальніших рис випливають і відповідні мовні характеристики, передусім це мовна внормованість, зокрема логічність викладу матеріалу зумовлюється, по-перше, послідовністю інформації, по-друге, специфічними мовними засобами (напр., складнопідрядними конструкціями $з$ причинно-наслідковими зв'язками). Прагнення до однозначності змісту призводить до збільшення ваги іменників. Отже, усі мовні засоби рецензії підпорядковані основному комунікативному завданню — передати думку 3 достатньою повнотою, логічно, переконливо й послідовно.

Рецензія, як зауважувалося, покликана дати оцінку тому чи тому явищу. Отже, така праця повинна впливати й на емоції читача, а це означає, що в ній значною мірою поєднуються мовні засоби, що використовуються в художньому й у публіцистичному стилях. Рецензент не лише викладає інформацію, але й акцентує увагу читача на позитивних і негативних елементах, намагається переконати в незаперечності викладених положень або ж довести іншу думку в полеміці 3 автором аналізованої книги. А тому, дотримуючись канонів функціонального підстилю науково-публіцистичної прози, жанр рецензії має виразну тенденцію до активного використання емоційно-експресивних компонентів для оцінки праці вченого: слів і зворотів розмовної мови, модальних слів зі значенням суб'єктивної оцінки, еліптичних конструкцій, окличних речень $з$ яскраво вираженою експресивністю, а також образів, порівнянь i метафор. Оцінюючи наукову працю, рецензент не намагається урізноманітнити способи вираження оцінки, а послуговується здебільшого вже готовими метафоричними оцінними кліше. Метафора в науковому стилі, як відомо, традиційна, стереотипна, не позначена впливом індивідуального, суб'єктивнооцінного чинника. Проте така метафора почасти перестає задовільняти авторів рецензії, які прагнуть викликати в читача емоційно-оцінну реакцію, певне ставлення до рецензованої публікації, а тому вони все частіше використо-

20 Літературознавчий словник-довідник, за ред. Р. Т. Гром’яка, Ю. І. Коваліва та ін., Київ 1997, c. 242.

${ }^{21}$ В. Г. Ляпунова, О. Д. Мешков, Е. В. Терехова, A book about books. Композиция и язык научных рецензий, Москва 1990, с. 5. 
вують із цією метою оригінальні образні засоби (яскраво ця тенденція виявляється в текстах літературознавчих рецензій).

Використання мовної образності в рецензії зумовлено особливостями композиційної побудови текстів цього жанру. В українській науковій літературі склалася традиційна архітектоніка цього типу тексту. Рецензія репрезентує єдність таких композиційних елементів, як заголовок, бібліографічний опис, вступ, основна частина, висновок. Кожний композиційний елемент $є$ закономірним етапом в оцінній характеристиці рецензованої публікації, має певну прагматичну настанову й отримує в тексті рецензії відповідне змістове та графічне оформлення.

Заголовок рецензії найчастіше містить у концентрованому вигляді інформацію про зміст рецензованої праці та забезпечує тим самим необхідну адресність наукової рецензії. Заголовок не містить безпосередньої оцінки публікації, а отже, не $\epsilon$ власне оцінним етапом. Проте, орієнтуючи на конкретну наукову проблему, заголовок рецензії все ж визначає спрямованість та інтенсивність уваги читача.

Характерною ознакою всіх, без винятку, рецензій $є$ наявність бібліографічного опису видання (може бути повним або скороченим, мати свої певні усталені варіанти розміщення в тексті - найчастіше бібліографічний опис розпочинає рецензію). Бібліографічний опис також не містить безпосередньої оцінки твору, але відомості, подані в ньому, дають змогу читачеві співвідносити їх з відповідними оцінними судженнями, зокрема вказівка на відоме видавництво дозволяє сподіватися високої якості друку, ілюстративного матеріалу, зовнішнього оформлення публікації.

Отже, не пропонуючи безпосередньої оцінки рецензованої праці, бібліографічний опис, проте, формує відповідний рівень оцінних очікувань реципієнта і разом із заголовком є попереднім етапом оцінки публікації.

Вступна частина оформляється здебільшого одним абзацом і містить в узагальненому вигляді всі основні різновиди інформації, типові для тексту журнальної рецензії. Специфічною ознакою цього композиційного елементу є те, що в ньому здійснюється перехід від етапу попередньої оцінки до етапу безпосередньої оцінки публікації: у вступі рецензент висловлює найзагальнішу оцінку аналізованої праці. У зв'язку з цим особливої вагомості набувають мовні засоби, спрямовані на те, щоб привернути увагу читача, вплинути на нього з метою створення відповідного ставлення до публікації.

Нерідко автор прямо повідомляє читачеві мету написання рецензії, не приховуючи суб'єктивної мотивації, зокрема до написання рецензії автора можуть спонукати рецензії інших дослідників, 3 оцінками яких він не погоджується загалом або має власну думку щодо окремих позицій (безпосередній вияв реактивності (термін О. Сальникової̈22) жанру), а отже, відбувається спілкування в якісно новій площині - діалог (здебільшого полемічний) рецензентів (рідше - полілог), наприклад: „Підручник уже має кілька схвальних рецензій, в яких висловлено й певні критичні зауваги. Так, рецензентів не переконав архаїзм , Уводини” як назва вступної частини. Попри позірну частковість, вважаю ие питання принциповим. Адже то не зовсім „вступне слово”, як здалося В. Лесикові, оскільки „Уводини” таки вводять студента в коло основних та літературознавчих дисииплін"з (тут і далі зазначаємо рік видання, номер і сторінку часопису). До речі, такий напрямок

22 3. С. Смелкова, Л. В. Ассуирова и др. Риторические основы журналистики. Работа над жанрами газеты, Москва 2002, с. 206.

${ }^{23}$ В. Нарівська, До питомого трунту літератури, [в:] “Слово і час”, 2000, № 1, с. 118. 
комунікації характеризується грунтовною аргументацією висловлених зауважень.

Привертає увагу вступна частина рецензії на книгу А. Русначенка „Розумом і серцем” (К., 1999). Аргументуючи написання рецензії, автор пояснює причину недотримання ним однієї 3 основних вимог жанру - оперативності. Він намагається переконати читача в доцільності такої рецензії, послуговуючись емоційно-експресивними засобами та прийомами (трансформація відомої приказки, епітети, метафори, лексеми зі зменшено-пестливими суфіксами тощо): „Краще прочитати й відгукнутися пізніше, аніж не прочитати та не відгукнутися ніколи - так доводиться пояснювати той факт, щуо нормальний i конче потрібний відгук на книгу (...) з'являється лише через два роки після ї̈ виходу в світ. Це - немалий час з огляду на нинішній темп надходження й ознайомлення з інформацією (...). Хоча, враховуючи український інформачійний вакуум, неодмінно присутній феномен незнання та байдужості до всього, щзо перебуває за межами (вузенькими) маленького власного світику, - могло бути й довше, а отже, підстав для депресії з изього приводу бути не можее"24.

Зауважимо, що нерідко ставлення рецензента до автора не лише зумовлює тональність тексту, посилює суб'єктивність, а й змінює оцінне спрямування критики, зокрема виникає наукова дискусія, об'єктом якої є вже не стільки первинний текст, скільки рецензія іншого автора, наприклад: „...Читаючи й перечитуючи рецензію, не йняв віри своїм очам: на ї̈ 13 сторінках не знайшлося місия для жодного слова (...) про достоӥнства двох робіт, жодного доброго слова на адресу їх автора, котрий потратив, мабуть, не менше 8-10 років копіткої праџі для опраџювання літератури, опублікованих і архівних джерел, підготовки текстів і їх публікації. I все ж найбільще вразила навіть не надмірно загострена критичність рецензї (якоюсь мірою такий підхід можна пояснити запальністю вдачі чи несприйняттям концепџії опонента), a різкість, безапеляційність, місиями й відверта нетактовність суджень, оцінок, висновків ї̈ автора"25. Як бачимо, спостерігається своєрідна „дифузія” характеристик автора дослідження та рецензента-опонента.

Вступ у рецензії, як видається, не має єдиної моделі; він може бути коротким і розгорнутим, поєднувати всі характерні для тексту рецензії різновиди інформації чи подавати тільки деякі з них.

Організаційним центром журнальної рецензії є основна частина - найбільш інформаційна ділянка оцінного тексту, основним завданням якої є детальніше ознайомлення читача зі змістом книги, висвітлення ііі ключових положень. Якщо у вступі рецензент ніби апріорно оцінює працю вченого, то в основній частині подає аргументований аналіз публікації, доводить, ілюструє свої положення. Пропонуючи читачеві огляд змісту книги, рецензент тими чи тими засобами висловлює власне ставлення до аналізованого матеріалу, дає оцінку праці, зокрема цю інформацію часто деталізують метатекстові одиниці (семантика згоди чи незгоди) на зразок: на жаль, шкода, справді, правда, щзоправда, на мою думку, на мій погляд, вважаємо, треба признати, слід відзначити та ін. Зрозуміло, що „прозора” семантика цих мовних одиниць дає можливість читачеві відразу з'ясувати авторську позицію щодо змісту рецензованої праці: чи погоджується він із науковцем, чи заперечує його міркування. Найчастіше рецензенти намагаються обмежитися найсуттєвішими заувагами щодо змісту праці

${ }^{24}$ Д. Матіяш, “Розумом і серием” Анатолія Русначенка, [в:] „Сучасність”, 2001, № 7-8, с. 156.

${ }_{25}$ В. Степанков, “Інтелектуальна рефлексія” чи місія “караючого архангела”?, [в:] „Сучасність”, 2000, № 5, с. 148. 
на противагу іï деталізованому переказу. Щоправда, Ігор Качуровський указує на комунікативну необхідність переказу книги за певних умов, порівн.: „переповідати зміст випадає лише тоді, коли твір знаний і приступний критиковірецензентові, а чи історикові літератури, натомість для читача - недосяэсний. А про той чи той твір, щуо з ним читач або вже ознайомився, або може ие зробити, належить говорити як про щзось тому читачеві відоме $i$ знане" 26. Дослідниця У. Жидек-Беднарчук щодо цього зауважує: „... Ідеальна рецензія повинна містити лише загальний переказ, але в контексті робіт, що репрезентують подібну методологію на тлі інших методологій разом із зауваженнями"27. Очевидно, варто погодитися $з$ думкою про недоцільність переказу всієї книги, адже рецензія має передусім зацікавити читача, спонукаючи до самостійного ознайомлення $з$ первинним текстом, тобто головна іiі прагматична функція - збільшити кількість читачів.

Простежуючи співвідношення позитивного й негативного в системі оцінювання, зауважимо, що позитивна оцінка має значно вищий коефіцієнт частотності; це пояснюється різними чинниками (нерідко рецензії мають замовний характер!). На ці обставини почасти вказують самі рецензенти.

Дискусія про доцільність написання „негативних” рецензій розпочалася ще в XIX ст., зокрема на сторінках часопису „Жите і слово” (щодо цього питання полеміку з М. Драгомановим вели І. Франко, А. Кримський, Л. Василевський, В. Щурат). Нерідко навіть в одному номері друкували протилежні за оцінкою рецензії („позитивна” I. Франка та „негативна” М. Драгоманова) ${ }^{28}$ на одну й ту ж працю. У 30-х роках XX ст., як відомо, з'явилися рецензії-,погроми" на книги „буржуазних націоналістів”. Практика написання „негативних” рецензій збереглася й до сьогодні.

Науковець, як видається, передусім повинен дотримуватися моральноетичних засад ведення дискусії. Принагідно варто звернути увагу на висновкову частину однієї з рецензій В. Степанкова. Цей автор висловлює побажання усім рецензентам: „Коли вже дуже закортить перебрати на себе місію „, караючого архангела” й влаштувати комусь з опонентів „чистилище”, слід пригадати слова Ісуса Христа й вчасно схаменутися. Ось вони: „Чому дивишся на скалку в оці брата твого, колоди ж у власнім очі не чуєш? І якможеш сказати братові твоєму: дай, брате, вийму скалку, щзо в твоїм оці, ти, щзо не бачиш колоди, яка у твоїм оцін? Лицеміре, вийми перше колоду з ока свого, і тоді побачиш, як вийняти скалку з ока брата твого" (Свангеліє від Луки)"'29.

Очевидно, виявом наукового такту в проекції на рецензію $є$ „дозування” інформації 3 ,мінусовою” позначкою. Водночас важливо аргументувати недоліки книги (тоді як достоїнства зазначаються переважно на рівні констатації), тому суттєвою характеристикою способу викладу цієї міні-теми в сучасних рецензіях є роздум (рідше полеміка); насамперед такий різновид основної частини тексту може репрезентуватися двома типами роздумів: а) роздум, що готує читача до певної оцінки книги, тобто оцінне судження знаходиться в постпозиції та становить своєрідний висновок; б) роздум, що міститься після узагальненої

${ }^{26}$ I. Качуровський, I. Качуровський, Деякі міркування над книжкою віршів Івана Багряного, [в:] “Сучасність”, 2000, № 4, с. 155.

${ }^{27} \mathrm{U}$. Żydek-Bednarczuk, Akty mowy $i$ strategie pragmatyczne $w$ recenzji naukowej, [w:] Język — człowiek - kultura, pod red. B. Czopek-Kopciuch, Piotrków Trybunalski, 2000, s. 12.

${ }^{28}$ Див.: „Житє і слово”, 1894, т. 1, кн. 2.

${ }^{29}$ В. С тепанков, Зазнач. джерело, с. 151. 
оцінки й обгрунтовує та аргументує іiі, тобто оцінне судження знаходиться у препозиції щодо роздуму. Полеміка насамперед спрямована на аналіз i критику недоліків публікації та передбачає наявність щонайменше двох елементів: по-перше, це ознайомлення з поглядами автора рецензованого твору; по-друге, - критика цих поглядів рецензентом і висловлення ним власної позиції. Отже, єдність цих двох компонентів тексту утворює полемічний блок рецензії, що традиційно маркується специфічними лексико-синтаксичними конструкціями.

Організація основної частини рецензії здебільшого зумовлена характером аналізованого твору: чи то опис окремих компонентів публікації, чи роздуми щодо концепції вченого, чи полеміка з автором твору. А отже, відповідно до того, яка форма висловлювання домінує в основній частині рецензії, доцільно вирізняти щонайменше чотири різновиди цього композиційного елемента: основна частина описового характеру; основна частина, орієнтована на роздум; основна частина полемічного типу та основна частина „дифузного” (мішаного) характеру. Безпосередньо зі способом викладу інформації пов'язаний ще один важливий чинник - ситуативний контекст спілкування; наприклад, якщо рецензія $є$ елементом дискусії між рецензентами щодо правомірності позитивної чи негативної оцінки певної книги, то з розвитком полеміки переважатиме емоційність оцінювання, тобто відбуватиметься суб'єктивація тексту.

Комунікативну специфіку організації тексту рецензії нерідко зумовлює сама особа рецензента, його вміння. Здебільшого рецензенти-письменники в оцінці доробку колеги послуговуються „образною критикою”зо, активно використовуючи епітети, порівняння, метафори, фразеологічні одиниці, прийом зіставлення та ін. Почасти в таких текстах „руйнується” традиційна структура рецензії, з'являються композиційні елементи інших жанрів (інколи ненаукових), як-от: епіграфи, постскриптуми тощо; наприклад, епіграф як елемент архітектоніки літературознавчої рецензії має, як відомо, факультативний характер. Однак він нерідко програмує тональність і спрямованість подальшого спілкування з читачем, тобто є своєрідним комунікативним маркером для адресата, наприклад, Ігор Бондар-Терещенко в рецензії-відповіді на висловлені критиками зауваження використовує епіграф із тексту Генрі Аміеля: „До якої міри шкідлива, заразлива і нездорова вічна усмішка байдужої критики! Наскільки згубний ичей безглуздий усміх, щзо все роз '̈̈дає, пересміює і руйнує, щзо розчаровується у будь-якому особистому обов'язкові, у будь-якій перехідній прихильності, i котрий прагне лише одного: зрозуміти, а не діяти! Цей склад мислення дуже небезпечний у нас, оскільки він заохочує всі погані інстинкти: розбещеність, неповагу, егоїстичний індивідуалізм, і призводить до соціального атомізму"з1.

Зрозуміло, що домінування в тексті лексем із негативними конотаціями (икідливий, заразливий, нездоровий, байдужий, згубний, безглуздий, небезпечний та ін.) „сигналізує” читачеві про ставлення рецензента до обговорюваного. До того ж, доповнення запропонованого епіграфу цитатою Георгія Іванова: „Хуже всех пишу критику я - либо в ножки, либо в морду. Притом по темпераменту больше тянет в морду", - підкреслює іронічну тональність (почасти з відтінком сарказму) власне тексту рецензії.

${ }^{30}$ Н. В. Кириченко, Функционирование средств экспрессивного синтаксиса в текстовой структуре научно-популярного произведения, [в:] Типология текста в функциональностилистическом аспекте, Пермь 1990, с. 18.

${ }^{31}$ I. Бондар - Терещенко, Критика критики, [в:] „Березіль”, 1999, № 9-10, с. 184. 
Складовим елементом висновків у рецензії $є$ вирази побажання щодо майбутнього аналізованої праці, окреслення кола можливих адресатів і т. ін. Прикметно, що висновковій частині характерна інтегрувальна функція, оскільки узагальнена оцінка, яка тут міститься, відображає оцінну спрямованість усього тексту рецензії (позитивну чи негативну) і завершує процес поступового накопичення, деталізації та конкретизації оцінної інформації. Вступ і висновок рецензії ніби обрамлюють основну частину — аналіз, опис, систему доведень. Така архітектоніка тексту наукової рецензії забезпечує його монолітність, логічну стрункість і композиційну довершеність.

Рецензія характеризується стилістичною гібридністю, оскільки поєднує елементи публіцистичного та наукового стилів. Основними вимогами до журнальної рецензії як жанру науково-публіцистичного підстилю є науковість, актуальність, оперативність, діалогічність, обгрунтованість і ясність у висловленні думок, композиційна єдність і (на що варто звернути особливу увагу) доброзичливість, дотримання вимог наукової етики.

Отже, сучасний рецензійний дискурс спрямовано на реалізацію таких основних функції: 1) репрезентація певного твору читачам (інформаційна); 2) його оцінка й осмислення в загальному контексті певної галузі (оцінна). Вони можуть по-різному реалізуватися в змістовому просторі тексту, що зумовлює існування варіантів і різновидів рецензій, у яких виявляються почасти риси інших жанрів (анотацій, листів, есе, нарисів тощо). Вторинними функціями передбачено рекламування рецензованої праці, вироблення критеріїв оцінки твору, продукування нових і вдосконалення наявних вербальних форм наукового етикету.

Головна мета рецензійного дискурсу — переконати читацьку аудиторію зумовлює його антропоспрямованість, що вимагає врахування когнітивних, психологічних і соціальних параметрів аудиторії, рівня освіти, фахової належності, віку тощо. На мовному рівні це виявляється передусім у виборі лексикосинтаксичних конструкцій.

Рецензія має два основні вектори: читач і автор рецензованого твору, проте нерідко можливий і третій - інший рецензент. Кожний елемент архітектоніки рецензії $\epsilon$ закономірним етапом в оцінній характеристиці аналізованої публікації, має певну прагматичну настанову й відповідне змістове та графічне оформлення в тексті. Проте найбільш інформаційним компонентом рецензії $\epsilon$ основна частина, в якій за допомогою накопичення часткових оцінок, мотивацій, аргументів складається загальна оцінна спрямованість тексту. 